\title{
Espejos oblicuos. Cinco miradas sobre feminismo y cine contemporáneo
}

Julia Kratje (comp.) (2020). Buenos Aires, La Cebra. 128 pp.

\section{( Patricio Fontana}

UBA/UNA/Conicet

Hace más de siete décadas, Éric Rohmer escribió un texto clave que ya desde su título - “El cine, arte del espacio"- se presenta como una posible respuesta a la pregunta baziniana acerca de qué es el cine. Espejos oblicuos, compilado y prologado por Julia Kratje, ratifica de varios modos esa afirmación de Rohmer. En efecto, tanto el texto liminar como los cinco artículos que conforman el libro insisten de diversas maneras en la relevancia del vínculo entre espacio y cine.

Además de presentar los cinco artículos y de sugerir relaciones entre ellos, en la "Introducción" Kratje realiza un recorrido breve y a la vez exhaustivo por lo que podríamos llamar los espacios de la mujer en el cine. Y esto no solo a propósito de cómo las mujeres $-y$ en especial sus cuerpos- aparecieron en el cine a lo largo de su historia, sino en cuanto a ellas en tanto realizadoras o también teóricas y críticas de este arte. No obstante, esa cartografía de los diferentes modos en que los feminismos abordaron el cine desde mediados de los años sesenta menos que delinear de manera fuerte el marco desde el que fueron escritos estos artículos despliega un espacio teórico abierto, de fronteras porosas, en el que $-y$ con el que- ellos dialogan.

Los cinco artículos ofrecen lecturas de filmes realizados por mujeres entre fines de la década de 1980 y la actualidad. En este sentido, Espejos oblicuos resulta un aporte a la tarea de visibilización de la mujer cineasta que la crítica feminista viene haciendo desde hace varias décadas: "volver visible un espacio relegado", para decirlo con palabras de Kratje. Pero además, estas cinco miradas son el resultado de una voluntad crítica que busca no solamente analizar argumentos o temas -es decir, no priorizar aquello que más fácilmente se puede destilar de una película como sinopsis o resumen-, sino ensayarse en algo más arduo: una escritura que dé cuenta y además reflexione sobre lo que, apresuradamente, podríamos llamar lo específicamente cinematográfico, aquello en principio irreductible al lenguaje verbal. Todos estos artículos, así, se arriesgan a una escritura ecfrástica no solo descriptiva -informar qué se ve o que se oye en estos filmes- sino analítica: traducir a palabras el potencial crítico de algunas imágenes y sonidos creados o registrados por cinco mujeres cineastas.

El primer trabajo, de Natalia Barrenha, plantea una lectura de Una semana solos, el segundo largometraje de ficción de Celina Murga, a propósito de cómo la puesta en escena de este filme permite advertir de qué maneras los barrios cerrados -ese es el lugar donde transcurre la película - instalan una espacialidad asfixiante y monótona que es el resultado de las paradójicas nociones de libertad y de seguridad desde las que fueron concebidos y que determinan relaciones sociales que no solo no propician sino que bloquean el vínculo con el otro: "la anulación del otro como semejante". En este sentido, Barrenha considera esta película en diálogo con la anterior de Murga, Ana y los otros, y así detecta que ambas exploran cómo las relaciones con el otro dependen en buena medida de los espacios y de cómo se los transita. La flânerie de Ana por la ciudad de Entre Ríos se opone así a los recorridos limitados, opresivos, de los que participan los niños y las niñas de Una semana solos por el barrio cerrado. Como otros de los artículos de este libro, el de Barrenha se detiene no solo en lo que se ve en el filme sino en lo que se escucha: en este caso cómo en el filme de Murga aquello que el barrio cerrado pretende expulsar visualmente irrumpe como sonido off $y$, de este modo, permite que ese afuera sea una "ausencia presente que inquieta".

Como el texto de Barrenha, el de Fernanda Alarcón se ocupa de un filme - Aire libre- en el que también el cine se ocupa de los modos de habitar. En este caso, Alarcón especula acerca de cómo en esta película de Anahí Berneri la historia de la construcción frustrada, 
por parte de la pareja protagónica conformada por Manuel y Lucía, de una casa en las afueras de la ciudad -en un entorno al "aire libre"- permite explorar cinematográficamente modos de relacionarse con distintos espacios (la ciudad, el campo, la casa de la infancia, el lugar de trabajo, la casa que se abandona, la casa que se construye) y, así, interrogarse sobre la posibilidad, o la imposibilidad, de que una pareja construya y habite zonas en común. La pregunta desde la cual Alarcón se acerca a este filme es: ¿qué subjetividades surgen de la conjunción de unas biografías y unos espacios? Pero Alarcón no solo se demora en los lazos afectivos y sexuales entre estos dos personajes y, así, en considerar cómo esta mujer y este hombre, por distintas razones, no logran construir un vínculo más o menos pleno, sino también en cómo algo que ocurre más allá de los límites de sus cuerpos - la naturaleza y más específicamente lo vegetal- aparece en Aire libre como aquello que desborda no solo lo individual sino lo humano.

El artículo de Marcela Visconti, consagrado al filme Gilda, de Lorena Muñoz, comienza estableciendo una definición de la noción de "puesta en escena" - “la materia del cine, entonces, son cuerpos en una escena dispuesta para su registro en imágenes y sonidos (que posteriormente podrán ser reproducidos)"-desde la que se aborda esta película y que, como de diversos modos sucede también en los otros artículos de este libro, hace foco en los cuerpos del cine y en especial en los cuerpos de las mujeres. El interés de Visconti por esta biopic no radica tanto en lo que este filme narra - cómo la maestra jardinera Míriam Alejandra Bianchi se transformó en Gilda, una de las cantantes de cumbia más populares de la Argentina y, luego de su muerte, en una leyenda- sino, antes bien, en cómo el cine produce "cuerpos femeninos" y, en este caso, cómo Muñoz y Natalia Oreiro, la actriz protagónica, logran una figuración de lo femenino que elude el lugar común esencialista del exceso y optan, en contraste, por un "régimen de lo austero". Es precisamente allí y no tanto, o no solo, en la historia de realización personal que se narra en Gilda, donde Visconti advierte el potencial emancipatorio de este filme.

El interés por las conexiones entre espacios e identidades está presente también en el análisis de Vagón fumador, dirigida por Verónica Chen, que propone Lucas Martinelli en el cuarto trabajo de
Espejos oblicuos. Una vez más, no se trata meramente de analizar un argumento sino de insistir aquí en cómo dos cuerpos -en este caso los de Andrés y Reni- trazan recorridos por el espacio urbano -y luego, en el caso de Reni, más allá de la ciudad-que se apartan de —o se solapan con-las temporalidades fuertes del capitalismo o de la heterosexualidad para postular identidades débiles que transgreden esos patrones normalizadores y practican otros ritmos por ejemplo, los ritmos de lo queer-y, por tanto, otras formas de vida. Así, por ejemplo, el cajero automático es considerado por Martinelli como un espacio que, en Vagón fumador, determina el quizá inevitable lazo económico entre los protagonistas pero, al mismo tiempo, resulta uno en el que ocurren asociaciones que zafan del dinero y sus lógicas.

El trabajo que cierra este libro, de María Aimaretti, se ocupa de analizar el cortometraje documental Siempreviva, realizado a fines de la década de 1980 por la documentalista boliviana Liliana De la Quintana y de las circunstancias que lo propiciaron. Aquí, nuevamente, el énfasis en los cuerpos y los espacios del cine permite vislumbrar cómo este documental sirvió para rescatar y visibilizar no solo una práctica que se apartó de los modos más ortodoxos de la sindicalización, sino también, y en especial, unos cuerpos del trabajo que, gracias al cine, siguen vivos luego de su desaparición. El cine, aquí, como también en los otros artículos de este volumen, aparece entonces considerado como una memoria de los cuerpos. Espejos oblicuos viene entonces a sugerir que las películas pueden no solo hacer visible lo que, por diversas razones, fue invisibilizado, sino también hacer una y otra vez presente - volver a la vida- lo efímero o perecedero: el cine, pues, como modo de conjurar un acaso inevitable olvido material.

Además de las precisas lecturas que cada uno ofrece de la labor de algunas importantes cineastas latinoamericanas contemporáneas, todos los textos de este libro propician de manera más general, como ya lo apunté, el ejercicio de una sensibilidad crítica de unas miradas-que priorice aquello que diferencia el cine de otras artes (por ejemplo, la literatura). Espejos oblicuos, por tanto, puede leerse también como una invitación a practicar otros modos de ser espectador; es decir, otros modos de ver películas $y$, entonces, como quería Gilles Deleuze, de pensar con ellas. 